\title{
The Potential of Goat Meat in the Red Meat Industry
}

\author{
Irene Rumbidzai Mazhangara ${ }^{1, *}$, Eliton Chivandi ${ }^{2}{ }^{\circ}$, John Fisher Mupangwa ${ }^{3}$ \\ and Voster Muchenje ${ }^{1}$ \\ 1 Department of Livestock and Pasture Science, University of Fort Hare, Private Bag X1314, \\ Alice 5700, South Africa \\ 2 School of Physiology, University of Witwatersrand, 7 York Road, Parktown, \\ Johannesburg 2193, South Africa \\ 3 Department of Animal Science and Natural Resources, University of Namibia, \\ P/Bag 13308, Windhoek, Namibia \\ * Correspondence: iruemazhangara@gmail.com; Tel.: +27-78-705-5534
}

Received: 10 May 2019; Accepted: 30 May 2019; Published: 4 July 2019

\begin{abstract}
Worldwide the consumption of chevon (goat meat) has increased largely due to its distinct nutritional attributes when compared to other red meats. In addition to being a good source of dietary protein for human beings, chevon comparatively has a lower total fat, saturated fatty acid and cholesterol content, which makes it a healthful product. Chevon's health promoting chemical composition fulfils the expectations of consumers' demand for healthful foods and thus explaining its growing popularity and increased demand. The increase in the popularity and demand of chevon is essential to contributing towards the increase in demand for animal-derived protein sources for human consumption, which is driven by an expansion in urban settlements, improving incomes, and the need for a better lifestyle. Despite chevon being established as lean red meat with low content of fat, cholesterol and saturated fatty acids, there are misconceptions regarding the perceived inferior quality of chevon compared to beef, pork or lamb among some consumers. This review seeks to provide evidence supporting the favorable nutritive characteristics of chevon and it being a healthful product that is poised to make a significant contribution to animal-derived foods for human consumption.
\end{abstract}

Keywords: chevon; consumer perspective; fatty acid profile; health impact; human population; meat; nutritional attributes

\section{Introduction}

Meat is an integral part of the human diet. It is one of the major sources of dietary protein, fat, vitamins and minerals for the human populace. Between 1961 and 2011, the global per capita meat $(\mathrm{kg} /$ person/year) consumption increased from $23.1 \mathrm{~kg}$ to $42.2 \mathrm{~kg}$ [1]. The demand for meat and animal products, globally, has been on the increase, although demand in the developing world has been occurring at a decreasing rate [2-4], while demand in developed countries has and continues to occur at an increasing rate [5]. In the developing world the expansion of urban settlements, an improvement in income and an increase in population are the major drivers. The observed demand in meat and animal products in the developing world over and above facilitating a food revolution has created tremendous opportunities for smallholder local producers as they tap into the ever increasing market $[5,6]$.

Over and above being a concentrated source of energy, the fats in meat mediate the absorption of fat-soluble vitamins, thus helping prevent potential deficiency of fat-soluble vitamins. Despite its positive nutritional attributes (source of quality protein, energy dense, and vitamin and mineral content), red meat is also rich in saturated fat and cholesterol [7]. Due to its high saturated fat and cholesterol content, it has been confirmed that the excessive consumption of red meat and products 
derived from it is associated with increased risk of developing metabolic derangements such as obesity, insulin resistance, and metabolic dysfunctions and their associated metabolic (type II diabetes, hypertension, atherosclerosis, metabolic syndrome, and cancer) diseases $[8,9]$.

Globally consumers have become more health conscious and are now aware and more equipped with pertinent information regarding the effect of the food, including meat they consume. This increased consumer awareness has resulted in the emergence of a consumer category that demands healthful foods. Compared to other red meats such as beef and lamb, chevon has lower fat, saturated fat and cholesterol content $[10,11]$ but a higher polyunsaturated fatty acid (PUFA) [12,13]. This chemical composition, in terms of the fat content and fatty acid profile, makes chevon a more healthful meat in comparison to other red meats. Thus, chevon has the potential to fill in a special market niche. As a direct consequence of its leanness and a health-beneficial fatty acid profile, the popularity of chevon on the global meat market is increasing as health-conscious consumers prefer leaner and healthier chevon $[11,12]$.

The human population is expected to grow to nine billion by 2050 [14,15]. This huge increase in population is envisaged to further increase the already high demand for meat and other animal-derived products for human consumption [5,16-18]. In order to be able to meet the increased demand, there is the need for sustainable and efficient meat and animal product production. This population-mediated increase in the demand of animal-derived protein for human consumption creates a huge potential for goats, which are known to thrive in marginal areas, to play a significant role in the supply of meat and other protein products [19].

Compared to cattle, sheep and pigs, less scientific investment has been made towards improving the productivity of goats [20]. This "lag" in the investment towards improving the productive traits of goats, could have resulted from the relegation of goats to low economic value by the developed world, and a preference by consumers for other meats compared to chevon [21]. These two aspects have hugely contributed to the mismatch in developmental investment into goat productivity and the potential of goats to contribute to animal production for human consumption.

However, despite this slow investment into the development of goats targeting improved productivity, chevon, due to its healthful chemical nutrient profile is potentially going to be the next major contributor of animal-derived protein for human consumption in the not too distant future. It is against this background that this review seeks to create an awareness of the goat population, highlight the merits of goats over other small ruminants, and interrogate the capacity to produce chevon on a large scale and also to create an awareness of the health and nutritional benefits of chevon as a dietary protein source for human consumption.

\section{Overview of the Goat Industry}

\subsection{Goat Populations}

Currently the global goat population is one billion lower compared to cattle and sheep which are at 1.5 billion and 1.2 billion, respectively [22]. Africa and Asia's goat populations contribute $38.7 \%$ and $55.4 \%$ of the global goat population, thus these areas are potentially major players in the goat industry value chain. Between the years 2006 and 2016, the world goat population increased by $19.3 \%$, while cattle and sheep increased by 6.7 and $6.8 \%$, respectively (Table 1). African and Asian countries constitute part of the developing countries and are characterized by huge rural areas that are dependent on subsistence farming. Due to goats being hardy, they are one of the most favoured and widely farmed small ruminants; hence their large numbers in African and Asian countries. These large numbers of goats in such resource poor communities present a tremendous opportunity for improved goat productivity and off-take. 
Table 1. Percentage changes in goat, cattle and sheep populations (2006-2016) Source: [22].

\begin{tabular}{|c|c|c|c|c|c|c|c|c|c|}
\hline & \multicolumn{3}{|c|}{ Goat Heads } & \multicolumn{3}{|c|}{ Cattle Heads } & \multicolumn{3}{|c|}{ Sheep Heads } \\
\hline & 2006 & 2016 & $\begin{array}{l}\text { Change\% } \\
\text { 2006-2016 }\end{array}$ & 2006 & 2016 & $\begin{array}{l}\text { Change\% } \\
2006-2016\end{array}$ & 2006 & 2016 & $\begin{array}{l}\text { Change \% } \\
\text { 2006-2016 }\end{array}$ \\
\hline Africa & $281,690,042$ & $387,667,193$ & 37.6 & $255,302,101$ & $324,844,768$ & 27.2 & $280,667,155$ & $351,579,045$ & 25.3 \\
\hline America & $38,039,407$ & $37,866,521$ & -0.5 & $514,635,694$ & $522,004,210$ & 1.4 & $92,064,930$ & $83,849,797$ & -8.9 \\
\hline Asia & $498,978,363$ & $556,019,726$ & 11.4 & $445,448,690$ & $470,224,322$ & 5.6 & $458,176,129$ & $511,711,463$ & 11.7 \\
\hline Europe & $17,915,841$ & $16,965,650$ & -5.3 & $128,737,713$ & $121,934,483$ & -5.3 & $136,628,505$ & $131,059,072$ & -4.1 \\
\hline Oceania & $3,747,638$ & $4,291,278$ & 14.5 & $38,711,880$ & $35,879,934$ & -7.3 & $131,125,242$ & $95,154,412$ & -27.4 \\
\hline World & $840,371,292$ & $1,002,810,368$ & 19.3 & $1,382,836,078$ & $1,474,887,717$ & 6.7 & $1,098,661,961$ & $1,173,353,790$ & 6.8 \\
\hline
\end{tabular}


In Asia, China, India, Pakistan and Bangladesh are home to large goat populations with Chinese goat populations constituting $14.85 \%$ of the global goat population [22]. Nigeria, Sudan and Ethiopia are the African countries with the most goats (Table 2) and their total goat population, 135,404,892 million, constitutes $13.5 \%$ of the global goat population [22].

Table 2. Top ten countries with the largest goat population in 2016 Source: [22].

\begin{tabular}{ccc}
\hline Country & Goat Numbers & \% of the Total \\
\hline China & $148,934,400$ & 14.85 \\
India & $133,874,637$ & 13.35 \\
Nigeria & $73,879,561$ & 7.37 \\
Pakistan & $70,300,000$ & 7.01 \\
Bangladesh & $56,083,240$ & 5.59 \\
Sudan & $31,325,105$ & 3.12 \\
Ethiopia & $30,200,226$ & 3.01 \\
Kenya & $26,745,916$ & 2.67 \\
Mongolia & $25,574,861$ & 2.55 \\
Mali & $22,141,497$ & 2.21 \\
\hline
\end{tabular}

\subsection{Goats: Adaptations and Economic Potential}

Goats have inherent physiological adaptations that allow them to survive in marginal areas where crop and livestock production is not suited. They have a mobile upper lip which allows them to select nutrient-rich browse [23]. Additionally, because of their ability to secrete proline-rich proteins that complex with tannins, thereby reducing the detrimental effects [24], goats are able to consume and digest tannin-rich browse and effectively extract nutrients from it $[25,26]$. Goats are also known to be capable of enduring prolonged water deprivation and are better able to withstand heat stress compared to sheep and cattle [27]. Due to their adaptations, compared to other small livestock, goats are a low maintenance option and are the preferred small ruminant by farmers, particularly those residing in areas that are semi-arid and arid and thus characterized by marginal farming potential [28].

With climate change mediating a change of most natural grass rangelands into veld characterized by less grass, but more of browse trees and shrubs [29], goats are, the more suitable species to be reared in such marginal areas due to their adaptability to efficiently exploit such environs [30]. Goats are the most prolific domesticated ruminant, thus, from both a production point of view and with regard to their potential for genetic improvement, both can be attained in a relatively short time period [12,19]. The high prolificacy can be exploited to ensure adequate market supply of chevon, whose demand is on the increase.

\subsection{Goat Breeds for Meat and Chevon Production Trends}

Goats reared for chevon constitute a major part of the global goat population [31]. Several goat breeds are used for chevon production. In southern Africa, the major meat breed is the Boer goat of South Africa [31]. This breed is known to produce chevon of premium quality [32,33]. The low maintenance Kiko goat of New Zealand is known for its lean meat [31]. The Black Bengals of Bangladesh are known to be excellent in producing quality meat [34]. The Anglo-Nubian goat is used as a dual purpose breed for milk and meat production [31].

Despite the fact that over the last decade, among livestock, goats have had the largest numerical increase, the goat production industry is still characterized by a lack of organized selection programs in most areas particularly in the developing world [35]. In developing countries goats are mainly randomly bred with very limited if any dedicated selection programs. Due to the availability of a few well characterized breeds for meat production, there is a tremendous potential in these developing countries to select and exploit some of the untapped goat genetic potential. In addition to limited selection, goat production in these developing countries is mostly typified by an extensive production system and poor record keeping. 
Despite the lack of well-organized selection programs, the global outlook of the chevon industry shows evidence of its tremendous potential to grow. The Food and Agriculture Organization Corporate Statistical Database(FAOSTAT), [22] in 2016, indicated that the total world meat production grossed $329,890,425$ tonnes, of which chevon contributed 5,621,333 tonnes, which constituted $2 \%$ of the total world meat production (Table 3). Of this contribution, Asia and Africa produced approximately $95 \%$ of the total world chevon (Table 4). This high production of chevon from these two continents points to both the importance and potential of chevon to be among the elements of household food security [20]. The global chevon production from 2006 to 2016 increased by 23.12\% (Figure 1). In terms of regions the percent increase in chevon production was $12.68 \%, 29.35 \%,-19.57 \%$ and $-1.66 \%$ in Africa, Asia, Europe and the Americas, respectively [22].

Table 3. Global meat production in 2016 Source: [22].

\begin{tabular}{ccc}
\hline Meat Type & Production (Tonnes) & \% of the Total \\
\hline Beef & $65,973,820$ & 20 \\
Chevon & $5,621,333$ & 2 \\
Chicken & $107,143,008$ & 32 \\
Mutton & $9,310,532$ & 3 \\
Pork & $118,168,709$ & 36 \\
Other & $23,673,023$ & 7 \\
Total & $329,890,425$ & 100 \\
\hline
\end{tabular}

Table 4. Global chevon production in 2016 Source: [22].

\begin{tabular}{ccc}
\hline Region & Chevon Production (Tonnes) & \% of the Total \\
\hline Africa & $1,244,109$ & 22 \\
America & 127,041 & 2 \\
Asia & $4,113,646$ & 73 \\
Europe & 98,934 & 2 \\
Oceania & 37,603 & 1 \\
World & $5,621,333$ & 100 \\
\hline
\end{tabular}

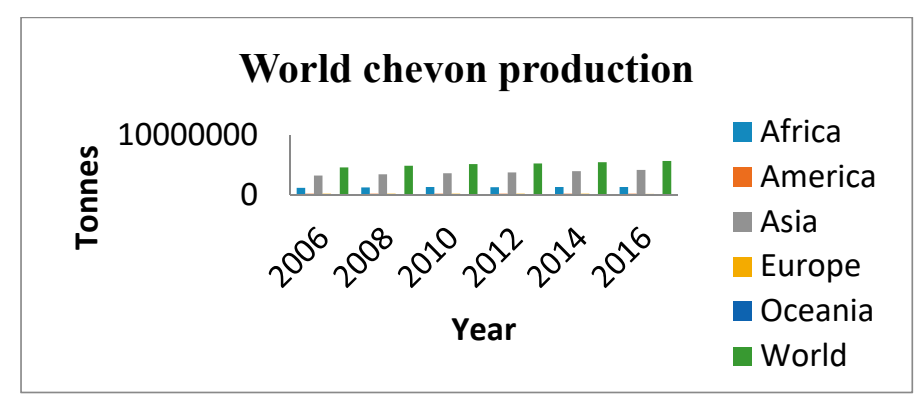

Figure 1. Global chevon production during the period 2006-2016 Source: [22].

\subsection{Trade and Marketing of Goats and Chevon}

Despite the economic importance of goats, particularly in the sustenance of household food security in rural areas of developing countries, marketing (of goats and chevon) is not as formalized as that of other livestock [36]. Other livestock production enterprises have functionally efficient production and marketing support structures which allow farmers to realize proper value from both the sale of live animals and or products derived from them. The inadequacy of pertinent literature regarding the marketing of goats and chevon also worsens the problems associated with a lack of formal goat and chevon marketing structures. Although this lack of an organized and streamlined marketing structure is largely true of the developing world, it is important to point out that even 
in countries from the developed world, goat and chevon marketing structures are less developed compared to that of other livestock species and products.

In most areas, chevon is mainly consumed locally and most of it is sold at local "markets" that cater for domestic consumption [37]. This localization of the trade and marketing of chevon results from it (chevon) being not as yet considered a mainstream product in many regions of the world despite its potential and health beneficial chemical nutrient composition. As a result, in both developed and developing countries, a major portion of chevon produced is not traded as other meats: it is largely usually produced and consumed locally in the communities where production takes place.

The localized informal chevon markets are typified and driven by traders who link mostly butchers to producers. In addition to the unavailability of formalized marketing for goats and chevon, the lack of a product grading system, poor quality product, seasonality of demand, inconsistent product supply and negative consumer attitudes, and insufficient research to identify a new market and expand existing markets $[38,39]$ compound the challenges faced by both goat producers and consumers of chevon.

In Africa and Asia, the demand for chevon is increasing despite the lack of a formalized marketing system. Besides being premised around social traditions and in some instances, ethnic demand, the demand for chevon is also influenced by religion as exemplified by the "Haji", a religious festival, where Moslems slaughter approximately 34 million sheep and goats in about six hours. Such religiously premised and other localized slaughters are executed outside of the abattoirs and largely constitute traditional forms of chevon consumption. Development of a formalized marketing structure would exploit both the religious-social mediated and modern chevon consumption habits which would stimulate the growth of the chevon industry.

\subsection{Chevon: Acceptability, Nutritional Value and Health Benefits}

Although chevon popularity and marketing support is not as well developed as that of other animals-derived dietary protein and micronutrient sources, chevon is generally well accepted across religions. It has none of the taboos associated with any other meat products such as beef and pork have among the Hindu and Muslim faiths, respectively. This is due to its wide accepted acceptability coupled with the increased demand of animal products in sub-Saharan Africa, expansion of urban settlements and an improvement in incomes [5] as well as the growth in living standards in some parts of the world. Thus, chevon can potentially increase its market share.

Globally consumers have become more health conscious and now exert strong influence regarding the acceptability and or boycott of certain foods. Over and above considering the sensory attributes, nutritional value and convenience factors associated with meat. Currently consumers demand lean meat with less saturated fatty acids, which has been demonstrated to have less negative impacts on health [40-43] compared to fatty meat rich in saturated fatty acids [44]. Besides being a good source quality protein for human consumption, chevon has a low fat and cholesterol content $[10,45,46]$, has a higher concentration of desirable and unsaturated fatty acids, which are known to have beneficial health effects in the human body [45,47].

Additionally, chevon which is leaner compared to other red meats, has favourable sensory and visual appeal [46]. Despite its favourable chemical nutrient composition and physical attributes, chevon is less recognized in the formal meat markets [48,49], is seen as a product for the poor and deemed an inferior product fit for the lower-income populace [50-52]. There is also a perception among consumers that chevon is stringy, tough and too strongly flavoured $[21,46,53]$. Despite some of these negative perceptions around chevon, its health benefiting fatty acid profiles and leanness clearly stand out and make it a potential significant contributor to the increased demand of animal products for human consumption.

Chevon is a low calorie, low fat and low cholesterol product [54] when compared to chicken, pork, beef and lamb (Table 5). Considering its high nutritional value and its greater unsaturated to saturated fatty acid ratio, chevon can potentially improve the health of human populations vulnerable 
to malnutrition with a much reduced risk of causing obesity and its associated metabolic diseases such as insulin resistance, type II diabetes mellitus, cardiovascular diseases and metabolic syndrome $[55,56]$.

Table 5. Chevon nutrient composition comparative chart Source: [54].

\begin{tabular}{ccccccc}
\hline $\begin{array}{c}\text { Per 85 g } \\
\text { Cooked/Roasted }\end{array}$ & Calories & Fat (g) & $\begin{array}{c}\text { Saturated } \\
\text { Fat }(\mathbf{g})\end{array}$ & $\begin{array}{c}\text { Cholesterol } \\
(\mathbf{m g})\end{array}$ & Protein (g) & Iron (mg) \\
\hline Chevon & 122 & 2.8 & 0.79 & 63.8 & 23 & 3.2 \\
Chicken & 162 & 6.3 & 1.7 & 76.0 & 25 & 1.5 \\
Beef & 179 & 7.9 & 3.0 & 73.1 & 25 & 2.9 \\
Pork & 180 & 8.2 & 2.9 & 73.2 & 25 & 2.7 \\
Lamb & 175 & 8.1 & 2.9 & 78.2 & 24 & 1.4 \\
\hline
\end{tabular}

Chevon is a major source of micronutrients particularly, iron and potassium as well as vitamin $\mathrm{B}_{12}$. Iron deficiency results in anemia and this is a real threat to women of childbearing age, especially in rural areas $[57,58]$. The high concentration of iron (Fe) in chevon (Table 5) makes it potentially a source of iron for pregnant women in rural areas where iron supplements may be difficult to access while high concentrations of potassium are essential for the maintenance of electrolyte and osmotic balance. Vitamin $B_{12}$ is required for normal maturation of erythrocytes with its deficiency leading to megaloblastic anemia.

The protein quality of a food is determined by the composition and proportion of essential amino acids in the food [50]. Compared to beef, pork, and lamb, chevon is characterized by having comparable arginine, isoleucine, lysine, methionine, threonine and tryptophan concentration (Table 6).

Table 6. Amino acid profile of beef, chevon, lamb and pork Source: [59].

\begin{tabular}{ccccc}
\hline \multirow{2}{*}{ Amino Acid } & \multicolumn{4}{c}{ Muscle Protein (mg Protein g) } \\
\cline { 2 - 5 } & Chevon & Beef & Pork & Lamb \\
\hline Alanine & - & 64 & 63 & 63 \\
Arginine & 75 & 66 & 64 & 69 \\
Aspartic & - & 88 & 89 & 85 \\
Cysteine & - & 14 & 13 & 13 \\
Glutamic & - & 144 & 145 & 144 \\
Glycine & 21 & 29 & 32 & 27 \\
Histidine & 21 & 29 & 32 & 27 \\
Isoleucine & 51 & 51 & 49 & 48 \\
Leucine & 84 & 84 & 75 & 74 \\
Lysine & 74 & 84 & 78 & 78 \\
Methionine & 27 & 23 & 25 & 23 \\
Phenylalanine & 35 & 40 & 41 & 39 \\
Proline & - & 54 & 46 & 48 \\
Serine & - & 38 & 40 & 39 \\
Threonine & 48 & 40 & 51 & 49 \\
Tryptophan & 15 & 11 & 13 & 13 \\
Tyrosine & - & 32 & 30 & 32 \\
Valine & 54 & 57 & 50 & 52 \\
\hline
\end{tabular}

\section{Potential for the Future}

\subsection{Research Promoting Goat Productivity}

In the discourse above, it is very clear that most of the goats are found in the developing countries of Africa and Asia and are thus largely reared by rural small-scale farmers. Despite these countries having large goat populations, Morand-Fehr and Boyazoglu [60] contend research in small ruminant production has been low, particularly in Africa. Although Europe has only $2 \%$ of the global goat 
population, it contributes $30 \%$ of the annual global scientific publications on small ruminants compared to Africa's $13.5 \%[60,61]$. While there has been some research regarding goat production, most of it has tended to focus on on-station and or commercial goat enterprises with little done with respect to improving and increasing goat productivity in rural communities. There is therefore a dire need to dedicate resources for research on goat nutrition, management, breeding and health in rural areas with the objective of improving productivity and off take. In addition to the fundamental need to execute research that targets to improve goat productivity, there is a need to make the research outputs farmer-friendly such research outcomes can be practically translated and transformed into practical knowledge to support primary production, hygienic-slaughter and chevon storage, grading and marketing.

\subsection{Chevon Market Development}

In developing countries where goats are reared, they are mostly farmed under natural veld with very little, if any, use of pharmacological agents to improve health and productivity. Thus, these goats and chevon derived from them can be deemed "green produce." It is imperative that this "naturalness and greenness" of such goats and products derived from them be emphasized when marketing them at local, regional and international levels. A marketing cocktail that highlights the health beneficial fatty acid composition and "naturalness" of the chevon not only helps educate the consumers of the benefits of the product, but it also creates a special niche for the product which will translate to greater benefit by producers. A deliberate effort needs to be made to showcase chevon as a unique product and avoid the traditional approach of benchmarking it against lamb. It is fundamental that beside the traditional manner of packaging and consumption of chevon, that it be also processed into various types of snack foods, or other convenience products tailored for specific ethnic or cultural groups in developed countries [62]. Apart from the value addition generated by the processing into snack and convenience foods, the processing also helps create demand in such developed societies.

Therefore, the chevon industry can take advantage of the growing demand for organic food [63]. This demand for organic food is mainly motivated by the consumers' health concerns [64]. Organic food can be defined as natural food items that are free from synthetic chemicals such as antibiotics, fertilizers, herbicides, pesticides and genetically modified organisms [65]. Furthermore, goat production can provide food security to the increasing world population, while minimizing negative impacts to the environment and health since the development of organic food production is largely driven by the idea of sustainability and environmental concerns [63].

In order to increase the demand for chevon and simultaneously increase chevon sales, market participants are encouraged to avert misconceptions of goat meat being regarded as inferior meat through synchronization of market preferences with the supply of the product. This will ensure that producers are able to access markets. Facilitating the formation of smallholder goat producer enterprises that are linked to processing units may also be a useful tool. Furthermore, integrating producers with marketing organizations will assure a quality goat meat supply in the local formal markets and also the export market.

Therefore, quality assurance schemes could be put in place to ensure the quality of chevon by exposing producers to production practices such as herd health, nutrition, management, and proper care, record keeping, and biosecurity. This marketing tool guarantees consumers the wholesomeness of their chevon and products. Efforts to increase goat productivity through increased carcass size and production efficiency should be the aim of development projects. This will avert low productivity, especially in terms of edible carcass per animal, thereby fulfilling local chevon demand and ensuring that export standards are met.

Putting in place comprehensive and comparable national chevon classification systems will promote the selection of chevon based on quality. This will also motivate individual farmers to produce a product of good quality when incentives are provided. Chevon classification systems will also ensure a shift from benchmarking chevon against lamb or mutton. As a result, the chevon industry 
development will be propped allowing chevon to be developed and marketed as a lean and healthy product. This will improve the recognition of chevon as an alternative source of good quality protein.

Therefore, windows of opportunity are open to establish marketing organizations that can capitalize on the growing demand for chevon. These organizations could add value to the products by undertaking to brand and ensuring the quality of the meat. Also, as production increases integrating smallholder producers into larger markets will allow access to buyers, processors, and suppliers of feeds and veterinary services. The aforementioned marketing tools are not only limited to countries in which there is a tradition of chevon consumption, but also European countries can apply them accordingly since the demand for healthy products of high nutritional value already exists.

\subsection{The Way Forward}

This overview of the situation of the world goat industry raises questions on the general opinion about goats as animals for poor people, on their potential for rural and local development, as well as for niche markets in urban communities. Furthermore, there is a projected twofold increase in the demand for safe, healthy, good quality meat and meat products by 2050 resulting from the dramatic growth in human population, improving lifestyles and urbanization $[5,14,15,17]$. Therefore, if goats contribute significantly to feeding rural populations, they certainly can also sufficiently supply meat in urban societies, provided an organized industry and marketing sector exist.

On the other hand, the world will be confronted with great water shortages, and a large demand by intensive water-using animal production systems can be questioned [5]. Goats can contribute to sustainable and productive use of water resources if their efficiency is improved by better adapted research and more efficient extension service. Therefore, the goat industry has great potential to grow in the global market.

\section{Conclusions}

Goats while known to play a significant role in human food security at household level, their contribution can be magnified by highlighting and creating awareness in the consuming public about the uniqueness of chevon, its being largely a natural product with a health beneficial fatty acid profile. Furthermore, an improvement in goat husbandry techniques, accurate record keeping and budgeting as well as the development of a formalized and well supported marketing structure is required in order for farmers to reap full benefits from goat farming and the sale of chevon. The creation of such awareness is bound to generate increased demand for the product which then avails more economic opportunities for goat farmers and the goat industry value chain. Therefore, opportunities exist for establishing marketing organizations at all levels from the village to national organizations that can take advantage of the growing demand for chevon.

This paper presents an interesting issue of chevon potential in the red meat industry, which might be particularly of importance to the meat producers, farmers in the developing African and Asian countries. This, therefore, calls for policy makers to create rapid and favourable policies, especially in the delivery of veterinary services and infrastructural development. Although demand for chevon is growing, it is not officially graded in most countries and this policy bottleneck limits the commercialization and marketing of chevon. Therefore, a chevon pricing and grading policy, if put in place, would promote the production of high-quality chevon thereby ensuring premiums for the producers and farmers. Ideally, this policy would also promote export earnings.

In conclusion, the adaptability and resilience of goats make them an indispensable resource to safeguard sustainable production and contribute to the increasing protein requirements of the growing human populace. This will call scientists in the near future to commence research on new technologies to improve the productivity and efficiency of goats.

Author Contributions: I.R.M., E.C. and V.M. conceptualized and designed the work. I.R.M. was accountable for drafting the manuscript. E.C. and J.F.M. proofread the manuscript. The authors of this manuscript approved the content of this manuscript. 
Funding: This research was funded by NATIONAL RESEARCH FUND COLLABORATIVE POSTGRADUATE TRAINING PROGRAMME, grant number 105289.

Acknowledgments: The authors are grateful to the Govan Mbeki Research and Development Centre, University of Fort Hare (GMRDC, UFH) for their support during this research.

Conflicts of Interest: The authors declare no conflict of interest.

\section{References}

1. Sans, P.; Combris, P. World meat consumption patterns: An overview of the last fifty years (1961-2011). Meat Sci. 2015, 109, 106-111. [CrossRef] [PubMed]

2. Grunert, K. Sustainability in the Food Sector: A Consumer Behaviour Perspective. Int. J. Food Syst. Dyn. 2011, 2, 207-218.

3. Grunert, K.G.; Hieke, S.; Wills, J. Sustainability labels on food products: Consumer motivation, understanding and use. Food Policy 2014, 44, 177-189. [CrossRef]

4. Reardon, T.; Timmer, C.P. Five inter-linked transformations in the Asian agrifood economy: Food security implications. Glob. Food Sec. 2014, 3, 108-117. [CrossRef]

5. Thornton, P.K. Livestock production: Recent trends, future prospects. Philos. Trans. R. Soc. B Biol. Sci. 2010, 365, 2853-2867. [CrossRef] [PubMed]

6. Delgado, C.L. Rising Consumption of Meat and Milk in Developing Countries Has Created a New Food Revolution. J. Nutr. 2003, 133, 3907S-3910S. [CrossRef] [PubMed]

7. Boada, L.D.; Henríquez-Hernández, L.A.; Luzardo, O.P. The impact of red and processed meat consumption on cancer and other health outcomes: Epidemiological evidences. Food Chem. Toxicol. 2016, 92, 236-244. [CrossRef] [PubMed]

8. Klurfeld, D.M. Research gaps in evaluating the relationship of meat and health. Meat Sci. 2015, 109, 86-95. [CrossRef]

9. Wang, X.; Lin, X.; Ouyang, Y.Y.; Liu, J.; Zhao, G.; Pan, A.; Hu, F.B. Red and processed meat consumption and mortality: Dose-response meta-analysis of prospective cohort studies. Public Health Nutr. 2016, 19, 893-905. [CrossRef]

10. Madruga, M.S.; Bressan, M.C. Goat meats: Description, rational use, certification, processing and technological developments. Small Rumin. Res. 2011, 98, 39-45. [CrossRef]

11. Ivanović, S.; Pavlović, I.; Pisinov, B. The quality of goat meat and its impact on human health. Biotechnol. Anim. Husb. 2016, 32, 111-122. [CrossRef]

12. Anaeto, M.; Adeyeye, J.A.; Chioma, G.O.; Olarinmoye, A.O.; Tayo, G.O. Goat products: Meeting the challenges of human health and nutrition. Agric. Biol. J. N. Am. 2010, 6, 1231-1236. [CrossRef]

13. Aghwan, Z.A.; Alimon, A.R.; Goh, Y.M.; Nakyinsige, K.; Sazili, A.Q. Fatty Acid Profiles of Supraspinatus, Longissimus lumborum and Semitendinosus Muscles and Serum in Kacang Goats Supplemented with Inorganic Selenium and Iodine. Asian-Australas. J. Anim. Sci. 2014, 27, 543-550. [CrossRef] [PubMed]

14. United Nations. World Population Projected to Reach 9.8 Billion in 2050, and 11.2 Billion in 2100. Available online: https://www.un.org/development/desa/en/news/population/world-population-prospects-2017.html (accessed on 8 May 2019).

15. Council, N.R. Critical Role of Animal Science Research in Food Security and Sustainability; National Academic Press: Washington, DC, USA, 2015.

16. Henchion, M.; McCarthy, M.; Resconi, V.C.; Troy, D. Meat consumption: Trends and quality matters. Meat Sci. 2014, 98, 561-568. [CrossRef] [PubMed]

17. Henchion, M.; Hayes, M.; Mullen, A.; Fenelon, M.; Tiwari, B.; Henchion, M.; Hayes, M.; Mullen, A.M.; Fenelon, M.; Tiwari, B. Future Protein Supply and Demand: Strategies and Factors Influencing a Sustainable Equilibrium. Foods 2017, 6, 53. [CrossRef]

18. Weber, G.M.; Windisch, W. Producing Sufficient Animal-Source Protein for the Growing World Population. In Sustainable Nutrition in a Changing World; Springer International Publishing: Cham, Switzerland, 2017; pp. 321-334.

19. Aziz, M.A. Present status of the world goat populations and their productivity. Lohmann Inf. 2010, 45, 42-52.

20. Dhanda, J.S.; Taylor, D.G.; Murray, P.J.; Pegg, R.B.; Shand, P.J. Goat Meat Production: Present Status and Future Possibilities. Asian-Australas. J. Anim. Sci. 2003, 16, 1842-1852. [CrossRef] 
21. Webb, E.C.; Casey, N.H. Physiological limits to growth and the related effects on meat quality. Livest. Sci. 2010, 130, 33-40. [CrossRef]

22. FAOSTAT Food and Agriculture Organization of the United Nations. Available online: http://www.fao.org/ faostat/en/\#data/QA (accessed on 8 May 2019).

23. Elias, D.; Tischew, S. Goat pasturing-A biological solution to counteract shrub encroachment on abandoned dry grasslands in Central Europe? Agric. Ecosyst. Environ. 2016, 234, 98-106. [CrossRef]

24. Alonso-Díaz, M.A.; Torres-Acosta, J.F.J.; Sandoval-Castro, C.A.; Hoste, H. Tannins in tropical tree fodders fed to small ruminants: A friendly foe? Small Rumin. Res. 2010, 89, 164-173. [CrossRef]

25. Silanikove, N. The physiological basis of adaptation in goats to harsh environments. Small Rumin. Res. 2000, 35, 181-193. [CrossRef]

26. Basha, N.A.D.; Scogings, P.F.; Dziba, L.E.; Nsahlai, I.V. Diet selection of Nguni goats in relation to season, chemistry and physical properties of browse in sub-humid subtropical savanna. Small Rumin. Res. 2012, 102, 163-171. [CrossRef]

27. Kaliber, M.; Koluman, N.; Silanikove, N. Physiological and behavioral basis for the successful adaptation of goats to severe water restriction under hot environmental conditions. Animal 2016, 10, 82-88. [CrossRef] [PubMed]

28. Simela, L.; Merkel, R. The contribution of chevon from Africa to global meat production. Meat Sci. 2008, 80, 101-109. [CrossRef] [PubMed]

29. O'Connor, T.G.; Puttick, J.R.; Hoffman, M.T. Bush encroachment in southern Africa: Changes and causes. Afr. J. Range Forage Sci. 2014, 31, 67-88. [CrossRef]

30. Monteiro, A.; Costa, J.; Lima, M. Goat System Productions: Advantages and Disadvantages to the Animal, Environment and Farmer; IntechOpen: London, UK, 2017.

31. Skapetas, B.; Bampidis, V. Goat production in the world: Present situation and trends. Livest. Res. Rural Dev. 2016, 28, 1-6.

32. Casey, N.H.; Webb, E.C. Managing goat production for meat quality. Small Rumin. Res. 2010, 89, $218-224$. [CrossRef]

33. Webb, E.C.; Pophiwa, P. Goat Meat Production in Resource-Constrained Environments and Methods to Improve Quality and Yield. In Sustainable Goat Production in Adverse Environments; Springer International Publishing: Cham, Switzerland, 2017; Volume I, pp. 195-209. ISBN 978-3-319-71855-2.

34. Amin, M.; Husain, S.; Islam, A.B.M. Evaluation of Black Bengal goats and their cross with the Jamunapari breed for carcass characteristics. Small Rumin. Res. 2000, 38, 211-215. [CrossRef]

35. Dubeuf, J.-P.; Boyazoglu, J. An international panorama of goat selection and breeds. Livest. Sci. 2009, 120, 225-231. [CrossRef]

36. Gandhi, S. A Study of Goat Meat (Chevon) Market Value Chains in Kumaon Region, Uttarakhand State; International Livestock Research Institute: New Delhi, India, 2015.

37. Dubeuf, J.-P.; Morand-Fehr, P.; Rubino, R. Situation, changes and future of goat industry around the world. Small Rumin. Res. 2004, 51, 165-173. [CrossRef]

38. Maganga, A.; Chigwa, F.; Mapemba, L. Goat and goat meat markets in selected districts of Malawi: Value chain, structure and efficiency. Livest. Res. Rural Dev. 2015, 27, 28560.

39. Yesufu, O.; Kassali, R.; Aremu, F.; Ojo, M. Market Analysis of Smallholder Goat Enterprise under Tropical Conditions. Agric. Trop. Subtrop. 2017, 50, 121-127. [CrossRef]

40. Monsón, F.; Sañudo, C.; Sierra, I. Influence of breed and ageing time on the sensory meat quality and consumer acceptability in intensively reared beef. Meat Sci. 2005, 71, 471-479. [CrossRef] [PubMed]

41. Muchenje, V.; Dzama, K.; Chimonyo, M.; Strydom, P.E.; Hugo, A.; Raats, J.G. Some biochemical aspects pertaining to beef eating quality and consumer health: A review. Food Chem. 2009, 112, 279-289. [CrossRef]

42. Hathwar, S.C.; Rai, A.K.; Modi, V.K.; Narayan, B. Characteristics and consumer acceptance of healthier meat and meat product formulations-A review. J. Food Sci. Technol. 2012, 49, 653-664. [CrossRef] [PubMed]

43. Joo, S.T.; Kim, G.D.; Hwang, Y.H.; Ryu, Y.C. Control of fresh meat quality through manipulation of muscle fiber characteristics. Meat Sci. 2013, 95, 828-836. [CrossRef] [PubMed]

44. Chikwanha, O.C.; Vahmani, P.; Dugan, M.E.R.; Mapiye, C. Nutritional enhancement of sheep meat fatty acid profile for human health and wellbeing. Food Res. Int. 2018, 104, 25-38. [CrossRef]

45. Banskalieva, V.; Sahlu, T.; Goetsch, A.L. Fatty acid composition of goat muscles and fat depots: A review. Small Rumin. Res. 2000, 37, 255-268. [CrossRef] 
46. Webb, E.C.; Casey, N.H.; Simela, L. Goat meat quality. Small Rumin. Res. 2005, 60, 153-166. [CrossRef]

47. Mahgoub, O.; Khan, A.; Al-Maqbaly, R.; Al-Sabahi, J.; Annamalai, K.; Al-Sakry, N. Fatty acid composition of muscle and fat tissues of Omani Jebel Akhdar goats of different sexes and weights. Meat Sci. 2002, 61, 381-387. [CrossRef]

48. Musara, J.; Chimvuramahwe, J.; Munyati, V.; Chivheya, R.; Mwadzingeni, L. Why Not Commercial Goat Production? Exploring Rural Communities' Preference for Livestock Enterprises. Case of Matsai Communal Area, Zimbabwe. J. Agric. Res. Dev. 2013, 3, 26-34.

49. Soji, Z.; Muchenje, V. Should the South African red meat classification system be revised or maintained? A review. S. Afr. J. Anim. Sci. 2017, 47, 583. [CrossRef]

50. Mahgoub, O.; Kadim, I.T.; Webb, E.C. Goat Meat Production and Quality; CABI: Wallingford, UK, 2012; ISBN 1845938496.

51. Cawthorn, D.-M.; Hoffman, L.C. The role of traditional and non-traditional meat animals in feeding a growing and evolving world. Anim. Front. 2014, 4, 6-12. [CrossRef]

52. Kannan, G.; Lee, J.H.; Kouakou, B. Chevon quality enhancement: Trends in pre- and post-slaughter techniques. Small Rumin. Res. 2014, 121, 80-88. [CrossRef]

53. Jacques, K.; Norwood, F. Consumer Preference for Goat Meat in a Blind Sensory Analysis. Sheep Goat Res. J. 2017, 32, 28-35.

54. United States Department of Agriculture. Composition of Foods Raw, Processed, Prepared USDA Nutrient Database for Standard Reference, Release 14. Available online: https:/www.ars.usda.gov/ARSUsrFiles/ 80400525/Data/SR14/sr14doc.pdf (accessed on 18 October 2018).

55. Shija, D.S.; Mtenga, L.A.; Kimambo, A.E.; Laswai, G.H.; Mushi, D.E.; Mgheni, D.M.; Mwilawa, A.J.; Shirima, E.J.M.; Safari, J.G. Chemical composition and meat quality attributes of indigenous sheep and goats from traditional production system in Tanzania. Asian-Australas. J. Anim. Sci. 2013, 26, 295-302. [CrossRef] [PubMed]

56. Malekian, F.; Khachaturyan, M.; Gebrelul, S.; Henson, J.F. Composition and Fatty Acid Profile of Goat Meat Sausages with Added Rice Bran. Int. J. Food Sci. 2014, 2014, 1-8. [CrossRef] [PubMed]

57. Darnton-Hill, I.; Mkparu, U.; Darnton-Hill, I.; Mkparu, U.C. Micronutrients in Pregnancy in Low- and Middle-Income Countries. Nutrients 2015, 7, 1744-1768. [CrossRef] [PubMed]

58. Mwangi, M.; Phiri, K.; Abkari, A.; Gbané, M.; Bourdet-Sicard, R.; Braesco, V.; Zimmermann, M.; Prentice, A.; Mwangi, M.N.; Phiri, K.S.; et al. Iron for Africa-Report of an Expert Workshop. Nutrients 2017, 9, 576. [CrossRef] [PubMed]

59. Pellett, P.L.; Young, V.R. Role of meat as a source of protein and essential amino acids in human protein nutrition. Adv. Meat Res. 1990, 6, 329-370.

60. Morand-Fehr, P.; Boyazoglu, J. Present state and future outlook of the small ruminant sector. Small Rumin. Res. 1999, 34, 175-188. [CrossRef]

61. Morand-Fehr, P.; Lebbie, S.H.B. Proposals for improving the research efficiency in goats. Small Rumin. Res. 2004, 51, 145-153. [CrossRef]

62. McMillin, K.W.; Brock, A.P. Production practices and processing for value-added goat meat. J. Anim. Sci. 2005, 83, E57-E68.

63. Ditlevsen, K.; Sandøe, P.; Lassen, J. Healthy food is nutritious, but organic food is healthy because it is pure: The negotiation of healthy food choices by Danish consumers of organic food. Food Qual. Prefer. 2019, 71, 46-53. [CrossRef]

64. Rana, J.; Paul, J. Consumer behavior and purchase intention for organic food: A review and research agenda. J. Retail. Consum. Serv. 2017, 38, 157-165. [CrossRef]

65. Marwa, G.M.; Scott, D. An extension of the benefit segmentation base for the consumption of organic foods: A time perspective. J. Mark. Manag. 2013, 29, 1701-1728.

(C) 2019 by the authors. Licensee MDPI, Basel, Switzerland. This article is an open access article distributed under the terms and conditions of the Creative Commons Attribution (CC BY) license (http://creativecommons.org/licenses/by/4.0/). 